\title{
The Multiple and Versatile Roles of Aureobasidium pullulans in the Vitivinicultural Sector
}

\author{
Despina Bozoudi ${ }^{D}$ and Dimitrios Tsaltas * \\ Cyprus University of Technology, 3036 Lemesos, Cyprus; despoina.bozoudi@cut.ac.cy \\ * Correspondence: dimitris.tsaltas@cut.ac.cy; Tel.: +357-25-00-2545
}

Received: 27 August 2018; Accepted: 4 October 2018; Published: 9 October 2018

check for updates

\begin{abstract}
The saprophytic yeast-like fungus Aureobasidium pullulans has been well documented for over 60 years in the microbiological literature. It is ubiquitous in distribution, being found in a variety of environments (plant surfaces, soil, water, rock surfaces and manmade surfaces), and with a worldwide distribution from cold to warm climates and wet/humid regions to arid ones. Isolates and strains of $A$. pullulans produce a wide range of natural products well documented in the international literature and which have been regarded as safe for biotechnological and environmental applications. Showing antagonistic activity against plant pathogens (especially post-harvest pathogens) is one of the major applications currently in agriculture of the fungus, with nutrient and space competition, production of volatile organic compounds, and production of hydrolytic enzymes and antimicrobial compounds (antibacterial and antifungal). The fungus also shows a positive role on mycotoxin biocontrol through various modes, with the most striking being that of binding and/or absorption. A. pullulans strains have been reported to produce very useful industrial enzymes, such as $\beta$-glucosidase, amylases, cellulases, lipases, proteases, xylanases and mannanases. Pullulan (poly- $\alpha-1,6$-maltotriose biopolymer) is an A. pullulans trademark product with significant properties and biotechnological applications in the food, cosmetic and pharmaceutical industries. Poly ( $\beta$-L-malic acid), or PMA, which is a natural biopolyester, and liamocins, a group of produced heavy oils and siderophores, are among other valuable compounds detected that are of possible biotechnological use. The fungus also shows a potential single-cell protein source capacity with high levels of nucleic acid components and essential amino acids, but this remains to be further explored. Last but not least, the fungus has shown very good biocontrol against aerial plant pathogens. All these properties are of major interest in the vitivinicultural sector and are thoroughly reviewed under this prism, concluding on the importance that A. pullulans may have if used at both vineyard and winery levels. This extensive array of properties provides excellent tools for the viticulturist/farmer as well as for the oenologist to combat problems in the field and create a high-quality wine.
\end{abstract}

Keywords: Aureobasidium pullulans; biotechnological applications; viticulture; enzymes; non-Saccharomyces yeasts

\section{Introduction}

The genus Aureobasidium includes members of a ubiquitous nature that are able to survive in a diverse range of habitats. Aureobasidium pullulans is one of the common organisms readily found in most phyllospheric habitats including grapevines, with high morphological and genetic diversity [1]. A. pullulans is a yeast-like fungus (Figure 1) frequently isolated from the phyllosphere and carposphere of fruits and vegetables crops [2], and is associated with the endophyte population of many plant species possessing high antagonistic activity [3]. A. pullulans is one of the predominant yeast species isolated from grape berries at all stages of maturity [4] and other vine tissues from both 
diseased and healthy vines [2]. This observed abundance led many scientists to explore its biocontrol potential for important grape diseases such as Botrytis grey mould [5], and for bunch rot caused by species of Aspergillus [6]. Interestingly, Dimakopoulou and coworkers [7] found that isolate of $A$. pullulans was as effective as commercial fungicides for bunch rots. A. pullulans may also degrade and detoxify ochratoxin A, preventing wine contamination [8]. Nowadays, A. pullulans' diverse habitats, environmental conditions with a repertoire of biochemical characteristics, make it a first -lass source for biotechnological uses even across boundaries. The biosafety of A. pullulans has been explored as well, although most studies are related to immunocompromised individuals undergoing surgical treatments, for severe injuries with open wounds or those suffering serious diseases (AIDS, pulmonary infections and chronic diseases). Reports describe the infections as serious due to their severity and difficulties in treatment, although the isolates were not exhibiting resistance. In addition, the fungus shows strong affinity to synthetic materials and surgically implanted Silastic devices [9]. Although outside the scope of this review, it is worth mentioning the potential role of pullulan in biomedical applications reviewed by Singh and coworkers [10].
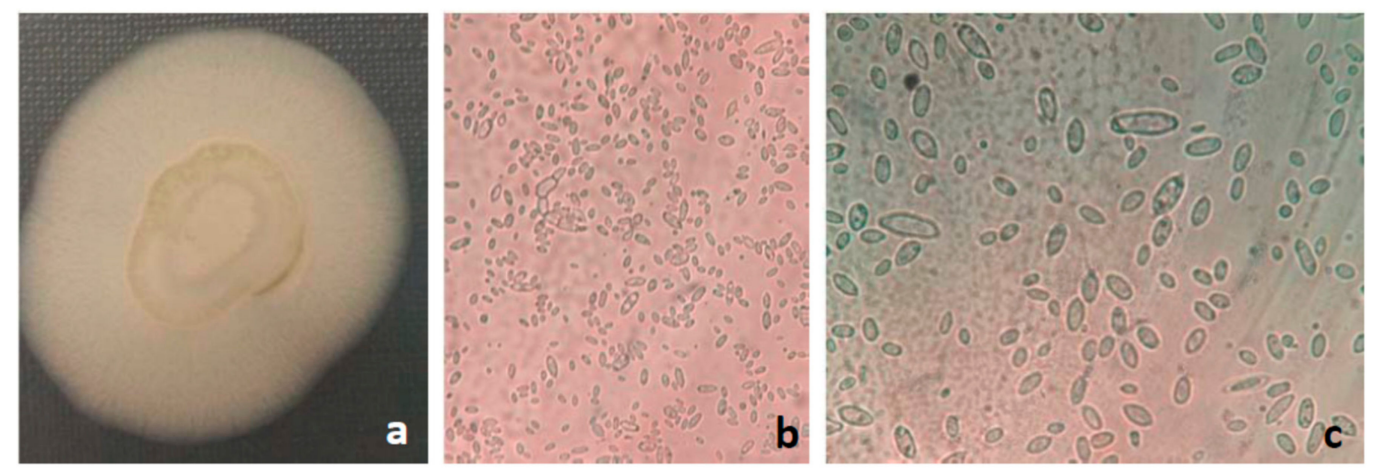

Figure 1. Aureobasidium pullulans (a) colony on Sabouraud Dextrose Agar (b) microscopic view of yeast-like cells with characteristic pseudomycelium, (c) characteristic microscopic view of yeast-like cells of various shapes and sizes.

\section{Distribution and Diversity}

As already mentioned, A. pullulans is characterized by its vast habitat presence. In the following, we will only refer to the presence of the fungus on the vine and must, although it is well practiced today that biotechnological applications could be across very isolated boundaries in order to make use of unique useful traits.

It has been recorded that soil, grape variety and grape growing practices influence the microbial ecosystem [11-13]. Microbial species present on the surface of grape berries at harvest play an important role in winemaking, and thus, counting and identifying them is of great importance. Studying several regions in the Bordeaux area, Renouf et al. [13] found that A. pullulans, the most widespread yeast species at the berry set, was never detected at harvest. Its number fell significantly at veraison, as it was superseded by fermentative yeasts, and was finally undetectable at harvest.

On the contrary, A. pullulans was found at significant high levels at studies conducted in Italy [14], Spain [15], Canada [16], Australia [4] and South Africa [17], while it often was isolated from Brazil, France, New Zealand, Greece and Slovenia, [18-22] as reviewed by Bozoudi and Tsaltas [12].

A. pullulans was also isolated from the grapes of the indigenous Cypriot varieties Xinisteri and Maratheftiko at low rates (6.29\%; Bozoudi et al., unpublished data). Work from Zalar et al. [23], on A. pullulans diversity, describes that the fungus occurs particularly in the phyllosphere. Although A. pullulans is one of the most abundant microorganisms on grape berries and other vine tissues, the diversity of Aureobasidium spp. on vine tissues has not been explored.

Rathnayake et al. [24] reported that the diversity of Aureobasidium isolates from different tissue types was greater than on a regional scale. The authors reported that the vineyards treated with no 
fungicides were having differences in colonization, having higher genetic variation in the Aureobasidium isolates observed. Additionally, they show that the Aureobasidium population may have been established for a long period of time, and being adapted to the climatic conditions. Alternatively, the introduction of rootstocks could have co-introduced new isolates. Therefore, it is possible that the genetic variation expressed by the Aureobasidium isolates from different vineyards in close proximity may be the result of evolution of these isolates over time in order to cope with different environmental selection pressures [24].

A. pullulans is characterized by high genetic variability [25]. Morphological and cultural characteristics alone are not sufficient to assess interspecific variability and to differentiate closely related strains. Thus, RAPD-PCR and other PCR techniques were used to successfully differentiate $A$. pullulans populations and to obtain information about the genetic complexity of this microorganism [26]. Small groups of strains of A. pullulans were described as varieties in the literature [23]. In 2014, [1] with the publication of four species' genome sequences, we cleared up significantly the knowledge of the genus and the discrimination of the species A. pullulans, A. melanogenum, A. subglaciale and A. namibiae. By comparison of their genomic data, Gostincar and coworkers showed that the differences between these "varieties" were large enough to justify their redefinition as four separate Aureobasidium species. These new data help address and explain the differences between strains and "varieties", which are of course attributed to different genetic material, coding for potentially different traits from the proteins that they encode. This work redefined clearly that the opportunistic human pathogens belong only to A. melanogenum, and we can now have a more clear understanding of the molecular background of Aureobasidium spp.

\section{Products}

A. pullulans has been known since 1891, as reported in the work of Cooke [27]. This allowed the scientific community to have gathered a substantial amount of information on the lifestyle and physiology of this fungus. A wide array of products have been isolated, characterized and tested for various biological and nonbiological functions. Antimicrobials, enzymes, polysaccharides, siderophores, polyesters and heavy oils are among the most prominent and will be reported analytically below.

\subsection{Antimicrobials}

Bacteria and yeasts are most likely to show a mutualistic behavior to each other in order to efficiently colonize the berries' surfaces. During these interactions on the berry surfaces, they may have increased nutrient-capture capabilities, resisting environmental stresses and interacting also with other categories of microorganisms such as moulds as well as viruses. Among yeast and bacteria, some species are known to have an antagonistic effect on mould development. A. pullulans is known to possess antagonistic properties towards other yeasts and fungi, and it can be speculated that it may influence the overall grape ecology [4].

It has been reported that $A$. pullulans exhibits reduction of Botrytis cinerea growth on the surface of table grape berries [13]. The proposed mechanisms explaining this antifungal activity were exclusion by bacteria and yeasts of fungal adhesion sites [28], competition for nutrients [29] and production of antagonistic metabolites or lytic enzymes. It is described that $A$. pullulans secretes chitinase and glucanase enzymes able to hydrolyse moulds [30]. In addition, an A. pullulans strain was found to produce antimicrobial compounds that were inhibitory towards the Gram-negative Pseudomonas fluorescens and Gram-positive Staphylococcus aureus bacteria [31]. The antibacterial activity of $A$. pullulans strains was attributed to 2-propylacrylic acid, 8,9-dihydroxy-2-methyl-4H,5H-pyrano [3,2-c]-chromon-4-one, 2-methylenesuccinic acid and hexane-1,2,3,5,6-hexol [32]. More work on antifungal properties was performed and a group of antifungals was named as aureobasidins. Aureobasidins are derivatives of cyclic deosipeptides (molar mass ranging 1070-1148 Da). Depending on their structures, aureobasidins are designated with the letters A to R [33]. Aureobasidin A seems to 
be reported in most cases, while work on factors affecting their production and activity has shown that glucose increases antifungal activity, and that the culture medium's amino acid composition has a variable role in some cases [34].

\subsection{Enzymes}

As reported above, enzymes may play a role as antimicrobials, but enzyme production and enzymatic activity have important roles in various biotechnological applications. A. pullulans is reported to produce amylases [35], cellulases [36], lipases [37], xylanases [38,39], proteases [40-42], laccase [43] and mannanases [44]. Currently in the wine industry, pectinases, glucanases, xylanases and proteases are used to improve the clarification and processing of wine. In addition, glycosidase is used for the release of varietal aromas from precursor compounds, urease for the reduction of ethyl carbamate formation, and glucose oxidase for the reduction of alcohol levels [45].

$\beta$-glucosidase has been also detected in A. pullulans [36,46,47] as well as glucose oxidase [48]. Urease activity has not been reported to the best of our knowledge. The work of Baffi et al. [49] is characteristic of the potential of non-Saccharomyces yeasts and their role in wine aroma, since they observed a notably increased amount of monoterpenes. Secreting cold-active pectinolytic activity has been also documented $[50,51]$ and has good potential in winemaking as well.

Lastly, of interest is the indirect role of enzymes in the possible microbial relations on the grape berries, because intact grape berry surfaces are likely to be poor in carbon. A. pullulans may well be a slowly rotting machine orchestrating the degradation of epidermal cells via pectolytic or cellulolytic activities, necessary to degrade pectin and cellulose, the most important plant cell constituents. A. pullulans produces extracellular pectolytic enzymes while growing on medium containing pectin as sole carbon source [52]. Also, pectinases are inducible in carbon starvation conditions according to Biely et al., [53] and pectinolytic activity of $A$. pullulans is maximum when pectin is the sole carbon source.

\subsection{Pullulan and Other Polysaccharides}

A. pullulans produces an extracellular and unbranched homopolysaccharide: the pullulan, which consists of $\alpha-(1 \rightarrow 6)$ linkages of $\alpha-(1 \rightarrow 4)$-linked maltotriose units [54]. This flexible and sticky polymer can form an oxygen-impermeable film, a property which is especially interesting to the understanding of the presence of several anaerobic bacteria on the berry. Moreover, the pullulan envelope may facilitate the adhesion of the bacterial cells to the berry surface. In order to preserve cell populations, the microorganisms need nutritive sources. The biofilm may act as a nutrient trap [55].

Pullulan production during initial fermentation stages by the fungus may help with must stabilization and improving mouth feel of wine due to the molecule's rheological properties in both aqueous and/or ethanolic media. Polysaccharides may also improve aroma and flavor delivery and perception also due to their physicochemical reactions with the aromatic compounds. In addition, polysaccharides (and pullulan) can retain better the colour and the antioxidant capacity of red wine.

Recently, other properties of pullulan have been explored, such as applications in medical sciences, particularly drug delivery, as well as the interaction of the molecule with various types of cells (liver, cancer cells) $[56,57]$. Such properties could be very interesting in the enhancement of the antioxidant role of red wine, as well as in the investigation of the beneficial role of wine in human health in general.

Other interesting extracellularly produced polysaccharides by $A$. pullulans include soluble $\beta$-glucan, consisting of a $\beta$-(1,3)-linked glucose main chain, and $\beta-(1,6)-$ linked glucose branches. $\beta$-glucan exhibits immune stimulatory activity, and is consumed as a supplement in many countries. Also, A. pullulans culture supernatant is believed to exhibit beneficial effects in delaying the onset of a number of diseases, and has been reported to exhibit antitumor, antiallergy and anti-infectious disease activities in mouse models [58-68]. An interesting review by Li et al. [69] on Aureobasidium spp. and biosynthesis and regulation of their extracellular polymers should be read by anyone interested in the field. 
Lastly, there is interest in wine waste as a substrate for A. pullulans growth and pullulan production [70-72]. Grape skin pulp is considered as one of the best substrates for pullulan production, especially hot water extracts of the pulp. The product is of higher molecular weight and rather pure.

\section{4. $P M A$}

Poly ( $\beta$-L-malic acid), or PMA, is a natural biopolyester produced by many microorganisms including A. pullulans. The interest in this molecule derives from its properties being biodegradable, water soluble and biocompatible, and its uses in the pharmaceutical industry [73-76]. No applications in the wine industry have been reported, but possible relationships can be explored via wine waste as substrate for PMA production and PMA as a coating for grape postharvest protection.

\subsection{Liamocins}

Back in 1994, Kurosawa et al. [77] discovered the production of heavy oils in the culture medium of Aureobasidium sp. In 2013, Price et al. [78] named them liamocins, and further clarified their molecular structure consisting of a single mannitol headgroup that is partially $\mathrm{O}$-acetylated with 3,5-dihydroxy-decanoic ester groups. Liamocins showed immediately their interesting biological activities as antimicrobials $[79,80]$ and anticancer agents [81,82].

Liamocins' role in plant disease control (grapes) and their role in wine in a technological aspect, as well as towards human health, remain to be explored.

\subsection{Siderophores}

Siderophores are low-molecular-weight high-affinity iron-chelating molecules that are produced by many microbes (fungi and bacteria) living under iron-depleted environments. The molecules help to sequester and solubilize the iron $\left(\mathrm{Fe}^{3+}\right.$ and $\mathrm{Fe}^{2+}$ ions). Siderophores are very interesting molecules for medical, agricultural and environmental applications, and have been of interest in biotechnology. Although only one strain of A. pullulans (HN6.2) has been reported in the literature to produce siderophores, studies of $A$. pullulans isolates report the effect and role of siderophores in biocontrol processes of plant and human pathogens [1,44,65,83-88].

\section{Single-Cell Protein}

With the world population reaching 9 billion by 2050, there is strong evidence that agriculture will not be able to meet the demand for food, and particularly protein, and as a result, food security is under serious threat. Common agriculture has serious drawbacks such as high water footprint, high land use, biodiversity loss, soil erosion, and contribution to climate change of a third of all greenhouse gases. For these reasons, food out of microbes is considered a sustainable way to proceed.

The biomass and protein extracted from cultures of fungi, bacteria and algae may be used as an ingredient or a substitute for protein-rich foods. Single-cell proteins (SCPs) refer to edible unicellular or multicellular microorganisms. The products are of high value, suitable for animal and human consumption, and efforts to grow SCP on agricultural and food waste as well as autotrophically are quite successful.

A. pullulans has not been explored for its use as a source of SCP, but fungi proteins have more advantages than those obtained from bacteria and algae [89]. Work from Chi et al. [90] showed that A. pullulans isolates had high levels of nucleic acid components and essential amino acids. Such properties could be helpful in wine fermentation if these components can be used for feeding the alcohol- and aroma-producing yeasts. Alternatively, dried, lysed A. pullulans cells can be a source of feed for wine fermenting yeasts $[91,92]$. 


\section{Biocontrol Agent}

A. pollulans' biocontrol capabilities have been explored for many years for diseases in both the field and post-harvest. In addition, diseases of the phylloplane and the carposphere, as well as diseases of the internal tissues, have been combated less or more successfully. The antagonistic feature of fungi may be attributed to competition for nutrients and space, parasitism on the fungal pathogens, secretion of antifungal compounds, attachment and biofilm formation, production of volatile organic compounds, as well as the induction of host plant resistance [93].

As a fast-growing yeast-like fungus, A. pullulans competes for nutrients as well as space. Extracellular polysaccharides, enzymes as well as other secreted molecules (liamocins, aureobasidins etc.) require significant amounts of carbon and nitrogen sources, as well as other micronutrients that are soon depleted from the environment and their competitors. In addition, pullulan and/or other high-MW molecules take space while at the same time creating a less favorable or even hostile environment for plant pathogens.

\subsection{Competition for Nutrients}

In 2006, Bencheqroum et al. [94] presented their first data that application of high amounts of exogenous amino acids, vitamins or sugars on apple wounds significantly reduced the protective level of A. pullulans, and in 2007, [95] the authors confirmed with in-vitro and in-situ evidence that competition for apple nutrients, most particularly amino acids, may be a main mechanism of the biocontrol activity of A. pullulans.

\subsection{Competition for Space}

Competition for space is amongst the most common but efficient ways in which biocontrol agents operate. Speedy growth helps a microorganism to dominate the space over slow growers. In addition, certain microbes occupy extra space with copious amounts of secreted polysaccharides that have both direct (occupying space) and indirect (attachment inhibitors, growth inhibitors etc.) roles on the growth of competitors. Schena and collaborators $[26,96]$ have tested various isolates from different sources (epiphytic and endophytic) of A. pullulans, and showed good results in biocontrol of various postharvest diseases of fruits and vegetables.

\subsection{Production of Volatile Organic Compounds}

Volatile organic compounds (VOCs) could play an essential role in the antagonistic activity of A. pullulans against postharvest pathogens. Mari et al. [97] suggested first that A. pullulans L1 and L8 strains could be considered as good candidates for the development of biofungicides. Compounds such as 2-phenyl, 1-butanol-3-methyl, 1-butanol-2-methyl and 1-propanol-2-methyl belonging to the group of alcohols are mainly produced from A. pullulans within 3-4 days of growth. 2-Phenethyl alcohol was determined as the most active, with $\mathrm{EC}_{50}$ values lower than $0.8 \mu \mathrm{L} \mathrm{ml}^{-1}$, responsible for reduction of vegetative growth and sporulation, and also reducing ochratoxin A (OTA) production and OTAbiosynthetic gene expression [98]. Similar results have been recently confirmed for other yeasts as well, [99] so it is worthwhile to revisit the A. pullulan isolates' VOCs capacity.

\subsection{Production of Hydrolytic Enzymes}

Hydrolytic enzymes were always considered first in biological control modes of action against pathogens. Chitinase and glucanase are amongst the most prominent enzymes having a role in biological agents' biocontrol activity. In addition, killer toxins have been attributed to have a role in fungal-fungal interactions $[100,101]$. 


\subsection{OTA Biodegradation, Detoxification and Absorption}

Mycotoxins could be decomposed, transformed or absorbed by microorganisms [102]. Their microbial degradation or transformation with specific attention to the actual detoxification is an important feature of various microorganisms [103]. De Felice and coworkers [104] showed that A. pullulans can transform OTA to OTA $\alpha$ on berries.

Yarrowia lipolytica Y-2 has the capacity to biodegrade OTA to OTA $\alpha$ through the hydrolytic activity of carboxypeptidases [105]. The same authors also support that, in addition, many proteins of $Y$. lipolytica $\mathrm{Y}-2$ involved in stress response and reactive $\mathrm{O}_{2}$ species elimination also play a role in OTA degradation. In the case of $A$. pullulans, carboxylpeptidases should be specifically explored for a similar role, though there are some toxicity issues regarding the use of enzymes to degrade OTA in wine because of their undesirable effects on must fermenting microbes [106]. More information can be found in an excellent review by Zang et al. [107]

\section{Aromatic Properties}

Microorganisms of enological interest have been grouped into three main classes: (a) easily controllable species without the ability to spoil wine when good manufacturing practices are applied, (b) fermenting species responsible for sugar and malic acid conversion, and (c) spoilage species [2]. As previously mentioned, A. pullulans holds a dominant position in most grapevine terroirs studied, and is classified in the first group. In grape microbiome reported work, A. pullulans emits typical, well-known flavour components of red wine (i.e., 2-methylbutanoic acid, 3-methyl-1-butanol and ethyl octanoate) [108]. It is not yet reported whether endophytic microorganisms have a role on grape aromatic compounds, but grapevine endophyte studies have progressed, and are very likely to identify such interplay in the near future $[109,110]$. Also, as referred to earlier (Section 3.2), $\beta$-glucosidase and pectinases have been involved in aroma production [49-51,111,112].

\section{Conclusions and Future Perspectives}

Aureobasidium pullulans' cosmopolitan presence has been well documented in the past 100 years. The list of properties (Table 1) of this yeast-like fungus is still growing. Here, we have presented what has been documented in relation to the microorganism and fruits, other microorganisms, as well as wine fermentation. A. pullulans has a vast potential in biotechnological uses, and in particular, in the vitivinicultural sector. In addition, new exotic isolates from extreme environments are likely to enhance significantly the repertoire of properties. Enzymes and metabolites of these isolates are very likely to help us resolve many technological problems requiring extreme solutions. In our conclusion, two major research directions are currently suggested, and these are: (1) reexamining all isolates in laboratory collections with the current knowledge of properties and molecular analysis tools (DNA/RNA level and proteins, including phylogenetics), and (2) exploring all known products of A. pullulans for novel uses and functions in the vitivinicultural sector, as described earlier. 
Table 1. Aureobasidium pullulans main properties.

\begin{tabular}{|c|c|c|c|}
\hline Main Property & Specific Property & Strain \# & Reference \\
\hline \multirow[t]{2}{*}{ Antimicrobials } & & FRR4800, WH9 & [28-30] \\
\hline & $\begin{array}{l}\text { Antibacterial } \\
\text { (Aureobasidins) }\end{array}$ & $\begin{array}{l}\text { NRRL 58561, NRRL 58562, } \\
\text { NRRL 58563, NRRL 58514, } \\
\text { NRRL 58536, NRRL 58516, } \\
\text { NRRL 58517, NRRL 58520 }\end{array}$ & [31-34] \\
\hline \multirow[t]{10}{*}{ Enzymes } & Lytic enzymes & & \\
\hline & Amylases & Cau19 & [113] \\
\hline & Cellulases & ER-16 & {$[36,114]$} \\
\hline & Lipases & HN2-3 & {$[37,115]$} \\
\hline & Xylanases & ATCC20524 & {$[38,39]$} \\
\hline & Proteases & HN2-3, 10, PLS & [40-42] \\
\hline & Laccase & NRRL50381 & {$[43,116]$} \\
\hline & Mannanase & & {$[44,117,118]$} \\
\hline & $\beta$-glucosidase & NRRL Y-12974, Ap-beta-gl & {$[36,46,49]$} \\
\hline & Pectinolytic & GM-R-22, LV-10 & {$[50-53,111]$} \\
\hline Pullulan & & $\begin{array}{c}\text { CGMCC1234, P56, CH1, ATCC } \\
\text { 201253, HP2001 }\end{array}$ & {$[54,56,119-122]$} \\
\hline$\beta$-glucan & & SM2001 & {$[58,59,61,63,64,66-68,123-125]$} \\
\hline PMA & & ССТССМ2012223 & [73-76] \\
\hline Liamocins & & NRRL 50380 & {$[78,126]$} \\
\hline Siderophores & & HN6.2, Y-1 & [83-87] \\
\hline Single-Cell Protein & & $\mathrm{G} 7 \mathrm{~b}, 4 \# 2$ & [90] \\
\hline Biocontrol & & $\begin{array}{l}\text { SL250, SL236, L47, Ach1-1, 533, } \\
\text { 547, L1, L8, ACBL77, LS30, } \\
\text { AU34-2 }\end{array}$ & {$[3,26,94-97,100,101,104,127,128]$} \\
\hline Aromatic Compounds & & T4B1c.17-P & [108] \\
\hline
\end{tabular}

Author Contributions: Conceptualization, D.T.; Writing-Original Draft Preparation, D.B.; Writing-Review \& Editing, D.T.; Funding Acquisition, D.T.

Funding: This work received no external funding.

Conflicts of Interest: The authors declare no conflict of interest.

\section{References}

1. Gostincar, C.; Ohm, R.A.; Kogej, T.; Sonjak, S.; Turk, M.; Zajc, J.; Zalar, P.; Grube, M.; Sun, H.; Han, J.; et al. Genome Sequencing of Four Aureobasidium pullulans Varieties: Biotechnological Potential, Stress Tolerance, and Description of New Species. BMC Genom. 2014, 15, 549. [CrossRef] [PubMed]

2. Barata, A.; Malfeito-Ferreira, M.; Loureiro, V. The Microbial Ecology of Wine Grape Berries. Int. J. Food Microbiol. 2012, 153, 243-259. [CrossRef] [PubMed]

3. De Curtis, F.; De Felice, D.V.; Ianiri, G.; De Cicco, V.; Castoria, R. Environmental Factors Affect the Activity of Biocontrol Agents against Ochratoxigenic Aspergillus Carbonarius on Wine Grape. Int. J. Food Microbiol. 2012, 159, 17-24. [CrossRef] [PubMed]

4. Prakitchaiwattana, C.J.; Fleet, G.H.; Heard, G.M. Application and Evaluation of Denaturing Gradient Gel Electrophoresis to Analyse the Yeast Ecology of Wine Grapes. FEMS Yeast Res. 2004, 4, 865-877. [CrossRef] [PubMed]

5. Parafati, L.; Vitale, A.; Restuccia, C.; Cirvilleri, G. Biocontrol Ability and Action Mechanism of Food-Isolated Yeast Strains against Botrytis Cinerea Causing Post-Harvest Bunch Rot of Table Grape. Food Microbiol. 2015, 47, 85-92. [CrossRef] [PubMed]

6. Pantelides, I.S.; Christou, O.; Tsolakidou, M.-D.; Tsaltas, D.; Ioannou, N. Isolation, Identification and In Vitro Screening of Grapevine Yeasts for the Control of Black Aspergilli on Grapes. Biol. Control 2015, 88, 46-53. [CrossRef]

7. Dimakopoulou, M.; Tjamos, S.E.; Antoniou, P.P.; Pietri, A.; Battilani, P.; Avramidis, N.; Markakis, E.A.; Tjamos, E.C. Phyllosphere Grapevine Yeast Aureobasidium pullulans Reduces Aspergillus Carbonarius (Sour Rot) Incidence in Wine-Producing Vineyards in Greece. Biol. Control 2008, 46, 158-165. [CrossRef] 
8. De Curtis, F.; De Cicco, V.; Lima, G. Efficacy of Biocontrol Yeasts Combined with Calcium Silicate or Sulphur for Controlling Durum Wheat Powdery Mildew and Increasing Grain Yield Components. Field Crops Res. 2012, 134, 36-46. [CrossRef]

9. Hawkes, M.; Rennie, R.; Sand, C.; Vaudry, W. Aureobasidium pullulans Infection: Fungemia in an Infant and a Review of Human Cases. Diagn. Microbiol. Infect. Dis. 2005, 51, 209-213. [CrossRef] [PubMed]

10. Singh, R.S.; Kaur, N.; Rana, V.; Kennedy, J.F. Pullulan: A Novel Molecule for Biomedical Applications. Carbohydr. Polym. 2017, 171, 102-121. [CrossRef] [PubMed]

11. Bokulich, N.A.; Thorngate, J.H.; Richardson, P.M.; Mills, D.A. Microbial Biogeography of Wine Grapes Is Conditioned by Cultivar, Vintage, and Climate. Proc. Natl. Acad. Sci. USA 2014, 111, E139-E148. [CrossRef] [PubMed]

12. Bozoudi, D.; Tsaltas, D. Grape Microbiome: Potential and Opportunities as a Source of Starter Cultures. In Grape and Wine Biotechnology; InTech: Rijeka, Croatia, 2016.

13. Renouf, V.; Claisse, O.; Lonvaud-Funel, A. Understanding the Microbial Ecosystem on the Grape Berry Surface through Numeration and Identification of Yeast and Bacteria. Aust. J. Grape Wine Res. 2005, 11, 316-327. [CrossRef]

14. Francesca, N.; Chiurazzi, M.; Romano, R.; Aponte, M.; Settanni, L.; Moschetti, G. Indigenous Yeast Communities in the Environment of "Rovello Bianco" Grape Variety and Their Use in Commercial White Wine Fermentation. World J. Microbiol. Biotechnol. 2010, 26, 337-351. [CrossRef]

15. Clavijo, A.; Calderón, I.L.; Paneque, P. Diversity of Saccharomyces and Non-Saccharomyces Yeasts in Three Red Grape Varieties Cultured in the Serrania de Ronda (Spain) Vine-Growing Region. Int. J. Food Microbiol. 2010, 143, 241-245. [CrossRef] [PubMed]

16. Subden, R.E.; Husnik, J.I.; Van Twest, R.; Van Der Merwe, G.; Van Vuuren, H.J.J. Autochthonous Microbial Population in a Niagara Peninsula Icewine Must. Food Res. Int. 2003, 36, 747-751. [CrossRef]

17. Setati, M.E.; Jacobson, D.; Bauer, F.F. Sequence-Based Analysis of the Vitis vinifera L. Cv Cabernet Sauvignon Grape Must Mycobiome in Three South African Vineyards Employing Distinct Agronomic Systems. Front. Microbiol. 2015, 6, 1358. [CrossRef] [PubMed]

18. Baffi, M.A.; dos Santos Bezerra, C.; Arévalo-Villena, M.; Briones-Pérez, A.I.; Gomes, E.; Da Silva, R. Isolation and Molecular Identification of Wine Yeasts from a Brazilian Vineyard. Ann. Microbiol. 2011, 61, 75-78. [CrossRef]

19. David, V.; Terrat, S.; Herzine, K.; Claisse, O.; Rousseaux, S.; Tourdot-Maréchal, R.; Masneuf-Pomarede, I.; Ranjard, L.; Alexandre, H. High-Throughput Sequencing of Amplicons for Monitoring Yeast Biodiversity in Must and during Alcoholic Fermentation. J. Ind. Microbiol. Biotechnol. 2014, 41, 811-821. [CrossRef] [PubMed]

20. Gayevskiy, V.; Goddard, M.R. Geographic Delineations of Yeast Communities and Populations Associated with Vines and Wines in New Zealand. ISME J. 2012, 6, 1281. [CrossRef] [PubMed]

21. Nisiotou, A.A.; Nychas, G.-J.E. Yeast Populations Residing on Healthy or Botrytis-Infected Grapes from a Vineyard in Attica, Greece. Appl. Environ. Microbiol. 2007, 73, 2765-2768. [CrossRef] [PubMed]

22. Raspor, P.; Milek, D.M.; Polanc, J.; Možina, S.S.; Čadež, N. Yeasts Isolated from Three Varieties of Grapes Cultivated in Different Locations of the Dolenjska Vine-Growing Region, Slovenia. Int. J. Food Microbiol. 2006, 109, 97-102. [CrossRef] [PubMed]

23. Zalar, P.; Gostincar, C.; de Hoog, G.S.; Ursic, V.; Sudhadham, M.; Gunde-Cimerman, N. Redefinition of Aureobasidium pullulans and Its Varieties. Stud. Mycol. 2008, 61, 21-38. [CrossRef] [PubMed]

24. Rathnayake, R.; Savocchia, S.; Schmidtke, L.M.; Steel, C.C. Characterisation of Aureobasidium pullulans Isolates from Vitis vinifera and Potential Biocontrol Activity for the Management of Bitter Rot of Grapes. Eur. J. Plant Pathol. 2018, 151, 593-611. [CrossRef]

25. Yurlova, N.A.; Mokrousov, I.V.; de Hoog, G.S. Intraspecific Variability and Exopolysaccharide Production in Aureobasidium pullulans. Anton. Leeuwenhoek 1995, 68, 57-63. [CrossRef]

26. Schena, L.; Ippolito, A.; Zahavi, T.; Cohen, L.; Nigro, F.; Droby, S. Genetic Diversity and Biocontrol Activity of Aureobasidium pullulans Isolates against Postharvest Rots. Postharvest Biol. Technol. 1999, 17, 189-199. [CrossRef]

27. Cooke, W.B. An Ecological Life History of Aureobasidium pullulans (De Bary) Arnaud. Mycopathol. Mycol. Appl. 1959, 12, 1-45. [CrossRef] [PubMed] 
28. Benbow, J.M.; Sugar, D. Fruit Surface Colonization and Biological Control of Postharvest Diseases of Pear by Preharvest Yeast Applications. Plant Dis. 1999, 83, 839-844. [CrossRef]

29. Vero, S.; Mondino, P.; Burgueno, J.; Soubes, M.; Wisniewski, M. Characterization of Biocontrol Activity of Two Yeast Strains from Uruguay against Blue Mold of Apple. Postharvest Biol. Technol. 2002, 26, 91-98. [CrossRef]

30. Ippolito, A.; El Ghaouth, A.; Wilson, C.L.; Wisniewski, M. Control of Postharvest Decay of Apple Fruit by Aureobasidium pullulans and Induction of Defense Responses. Postharvest Biol. Technol. 2000, 19, 265-272. [CrossRef]

31. McCormack, P.J.; Wildman, H.G.; Jeffries, P. Production of Antibacterial Compounds by Phylloplane-Inhabiting Yeasts and Yeastlike Fungi. Appl. Environ. Microbiol. 1994, 60, 927-931. [PubMed]

32. Zain, M.E.; Awaad, A.S.; Razak, A.A.; Maitland, D.J.; Khamis, N.E.; Sakhawy, M.A. Secondary Metabolites of Aureobasidium pullulans Isolated from Egyptian Soil and Their Biological Activity. J. Appl. Sci. Res. 2009, 5, 1582-1591.

33. Takesako, K.; Ikai, K.; Haruna, F.; Endo, M.; Shimanaka, K.; Sono, E.; Nakamura, T.; Kato, I.; Yamaguchi, H. Aureobasidins, New Antifungal Antibiotics. Taxonomy, Fermentation, Isolation, and Properties. J. Antibiot. 1991, 44, 919-924. [CrossRef] [PubMed]

34. Prasongsuk, S.; Ployngam, S.; Wacharasindhu, S.; Lotrakul, P.; Punnapayak, H. Effects of Sugar and Amino Acid Supplementation on Aureobasidium pullulans NRRL 58536 Antifungal Activity against Four Aspergillus Species. Appl. Microbiol. Biotechnol. 2013, 97, 7821-7830. [CrossRef] [PubMed]

35. Manitchotpisit, P.; Skory, C.D.; Leathers, T.D.; Lotrakul, P.; Eveleigh, D.E.; Prasongsuk, S.; Punnapayak, H. Alpha-Amylase Activity during Pullulan Production and Alpha-Amylase Gene Analyses of Aureobasidium pullulans. J. Ind. Microbiol. Biotechnol. 2011, 38, 1211-1218. [CrossRef] [PubMed]

36. Leite, R.S.; Bocchini, D.A.; Martins Eda, S.; Silva, D.; Gomes, E.; Da Silva, R. Production of Cellulolytic and Hemicellulolytic Enzymes from Aureobasidium Pulluans on Solid State Fermentation. Appl. Biochem. Biotechnol. 2007, 137-140, 281-288.

37. Leathers, T.D.; Rich, J.O.; Anderson, A.M.; Manitchotpisit, P. Lipase Production by Diverse Phylogenetic Clades of Aureobasidium pullulans. Biotechnol. Lett. 2013, 35, 1701-1706. [CrossRef] [PubMed]

38. Manitchotpisit, P.; Leathers, T.D.; Peterson, S.W.; Kurtzman, C.P.; Li, X.L.; Eveleigh, D.E.; Lotrakul, P.; Prasongsuk, S.; Dunlap, C.A.; Vermillion, K.E.; et al. Multilocus Phylogenetic Analyses, Pullulan Production and Xylanase Activity of Tropical Isolates of Aureobasidium pullulans. Mycol. Res. 2009, 113 Pt 10, 1107-1120. [CrossRef] [PubMed]

39. Ohta, K.; Fujimoto, H.; Fujii, S.; Wakiyama, M. Cell-Associated Beta-Xylosidase from Aureobasidium pullulans ATCC 20524: Purification, Properties, and Characterization of the Encoding Gene. J. Biosci. Bioeng. 2010, 110, 152-157. [CrossRef] [PubMed]

40. Chi, Z.; Ma, C.; Wang, P.; Li, H.F. Optimization of Medium and Cultivation Conditions for Alkaline Protease Production by the Marine Yeast Aureobasidium pullulans. Bioresour. Technol. 2007, 98, 534-538. [CrossRef] [PubMed]

41. Ma, C.; Ni, X.; Chi, Z.; Ma, L.; Gao, L. Purification and Characterization of an Alkaline Protease from the Marine Yeast Aureobasidium pullulans for Bioactive Peptide Production from Different Sources. Mar. Biotechnol. 2007, 9, 343-351. [CrossRef] [PubMed]

42. Ni, X.; Chi, Z.; Ma, C.; Madzak, C. Cloning, Characterization, and Expression of the Gene Encoding Alkaline Protease in the Marine Yeast Aureobasidium pullulans 10. Mar. Biotechnol. 2008, 10, 319-327. [CrossRef] [PubMed]

43. Rich, J.O.; Leathers, T.D.; Anderson, A.M.; Bischoff, K.M.; Manitchotpisit, P. Laccases from Aureobasidium pullulans. Enzym. Microb. Technol. 2013, 53, 33-37. [CrossRef] [PubMed]

44. Chi, Z.; Wang, F.; Chi, Z.; Yue, L.; Liu, G.; Zhang, T. Bioproducts from Aureobasidium pullulans, a Biotechnologically Important Yeast. Appl. Microbiol. Biotechnol. 2009, 82, 793-804. [CrossRef] [PubMed]

45. Van Oort, M.; Canal-Llaubères, R.-M.; Law, B.A. Enzymes in Wine Production. In Enzymes in Food Technology; Sheffield Academic Press: Sheffield, UK, 2002; pp. 76-90.

46. Iembo, T.; Da-Silva, R.; Pagnocca, F.C.; Gomes, E. Production, Characterization and Properties of Beta-Glucosidase and Beta-Xylosidase from a Strain of Aureobasidium Sp. Prikl. Biokhim. Mikrobiol. 2002, 38, 639-643. [PubMed] 
47. Leite, R.S.R.; Alves-Prado, H.F.; Cabral, H.; Pagnocca, F.C.; Gomes, E.; Da-Silva, R. Production and Characteristics Comparison of Crude $\beta$-Glucosidases Produced by Microorganisms Thermoascus Aurantiacus e Aureobasidium pullulans in Agricultural Wastes. Enzym. Microb. Technol. 2008, 43, 391-395. [CrossRef]

48. Smotrova, N.G.; Kremenchutskii, G.N. Isolation from the Environment of Strains of Microorganisms with Glucose Oxidase Activity. Mikrobiol. Zh. 2002, 64, 28-34.

49. Baffi, M.A.; Tobal, T.; Lago, J.H.; Boscolo, M.; Gomes, E.; Da-Silva, R. Wine Aroma Improvement Using a Beta-Glucosidase Preparation from Aureobasidium pullulans. Appl. Biochem. Biotechnol. 2013, 169, 493-501. [CrossRef] [PubMed]

50. Merin, M.G.; Mendoza, L.M.; Farias, M.E.; Morata de Ambrosini, V.I. Isolation and Selection of Yeasts from Wine Grape Ecosystem Secreting Cold-Active Pectinolytic Activity. Int. J. Food Microbiol. 2011, 147, 144-148. [CrossRef] [PubMed]

51. Merin, M.G.; Morata de Ambrosini, V.I. Kinetic and Metabolic Behaviour of the Pectinolytic Strain Aureobasidium pullulans GM-R-22 during Pre-Fermentative Cold Maceration and Its Effect on Red Wine Quality. Int. J. Food Microbiol. 2018, 285, 18-26. [CrossRef] [PubMed]

52. Manachini, P.L.; Parini, C.; Fortina, M.G. Pectic Enzymes from Aureobasidium pullulans LV 10. Enzym. Microb. Technol. 1988, 10, 682-685. [CrossRef]

53. Biely, P.; Heinrichová, K.; Kru, M. Induction and Inducers of the Pectolytic System in Aureobasidium pullulans. Curr. Microbiol. 1996, 33, 6-10. [CrossRef]

54. Seo, H.P.; Son, C.W.; Chung, C.H.; Jung, D.I.; Kim, S.K.; Gross, R.A.; Kaplan, D.L.; Lee, J.W. Production of High Molecular Weight Pullulan by Aureobasidium pullulans HP-2001 with Soybean Pomace as a Nitrogen Source. Bioresour. Technol. 2004, 95, 293-299. [CrossRef] [PubMed]

55. Filonow, A.B.; Vishniac, H.S.; Anderson, J.A.; Janisiewicz, W.J. Biological Control of Botrytis Cinerea in Apple by Yeasts from Various Habitats and Their Putative Mechanisms of Antagonism. Biol. Control 1996, 7, 212-220. [CrossRef]

56. Fundueanu, G.; Constantin, M.; Ascenzi, P. Preparation and Characterization of PH-and Temperature-Sensitive Pullulan Microspheres for Controlled Release of Drugs. Biomaterials 2008, 29, 2767-2775. [CrossRef] [PubMed]

57. Prajapati, V.D.; Jani, G.K.; Khanda, S.M. Pullulan: An Exopolysaccharide and Its Various Applications. Carbohydr. Polym. 2013, 95, 540-549. [CrossRef] [PubMed]

58. Ikewaki, N.; Fujii, N.; Onaka, T.; Ikewaki, S.; Inoko, H. Immunological Actions of Sophy Beta-Glucan (Beta-1,3-1,6 Glucan), Currently Available Commercially as a Health Food Supplement. Microbiol. Immunol. 2007, 51, 861-873. [CrossRef] [PubMed]

59. Jung, M.Y.; Kim, J.W.; Kim, K.Y.; Choi, S.H.; Ku, S.K. Polycan, a Beta-Glucan from Aureobasidium pullulans SM-2001, Mitigates Ovariectomy-Induced Osteoporosis in Rats. Exp. Ther. Med. 2016, 12, 1251-1262. [CrossRef] [PubMed]

60. Aoki, S.; Iwai, A.; Kawata, K.; Muramatsu, D.; Uchiyama, H.; Okabe, M.; Ikesue, M.; Maeda, N.; Uede, T. Oral Administration of the Aureobasidium pullulans-Derived Beta-Glucan Effectively Prevents the Development of High Fat Diet-Induced Fatty Liver in Mice. Sci. Rep. 2015, 5, 10457. [CrossRef] [PubMed]

61. Kataoka-Shirasugi, N.; Ikuta, J.; Kuroshima, A.; Misaki, A. Antitumor Activities and Immunochemical Properties of the Cell-Wall Polysaccharides from Aureobasidium pullulans. Biosci. Biotechnol. Biochem. 1994, 58, 2145-2151. [CrossRef] [PubMed]

62. Kawata, K.; Iwai, A.; Muramatsu, D.; Aoki, S.; Uchiyama, H.; Okabe, M.; Hayakawa, S.; Takaoka, A.; Miyazaki, T. Stimulation of Macrophages with the Beta-Glucan Produced by Aureobasidium pullulans Promotes the Secretion of Tumor Necrosis Factor-Related Apoptosis Inducing Ligand (TRAIL). PLoS One 2015, 10, e0124809. [CrossRef] [PubMed]

63. Ku, S.K.; Kim, J.W.; Cho, H.R.; Kim, K.Y.; Min, Y.H.; Park, J.H.; Kim, J.S.; Park, J.H.; Seo, B.I.; Roh, S.S. Effect of Beta-Glucan Originated from Aureobasidium pullulans on Asthma Induced by Ovalbumin in Mouse. Arch. Pharm. Res. 2012, 35, 1073-1081. [CrossRef] [PubMed]

64. Muramatsu, D.; Iwai, A.; Aoki, S.; Uchiyama, H.; Kawata, K.; Nakayama, Y.; Nikawa, Y.; Kusano, K.; Okabe, M.; Miyazaki, T. Beta-Glucan Derived from Aureobasidium pullulans Is Effective for the Prevention of Influenza in Mice. PLoS ONE 2012, 7, e41399. [CrossRef] [PubMed] 
65. Prasongsuk, S.; Lotrakul, P.; Ali, I.; Bankeeree, W.; Punnapayak, H. The Current Status of Aureobasidium pullulans in Biotechnology. Folia Microbiol. 2018, 63, 129-140. [CrossRef] [PubMed]

66. Tanaka, K.; Tanaka, Y.; Suzuki, T.; Mizushima, T. Protective Effect of Beta-(1,3 $\rightarrow$ 1,6)-D-Glucan against Irritant-Induced Gastric Lesions. Br. J. Nutr. 2011, 106, 475-485. [CrossRef] [PubMed]

67. Zhang, W.; Yu, X.; Kwak, M.; Xu, L.; Zhang, L.; Yu, Q.; Jin, J.O. Maturation of Dendritic Cells by Pullulan Promotes Anti-Cancer Effect. Oncotarget 2016, 7, 44644-44659. [CrossRef] [PubMed]

68. Lim, J.-M.; Do, E.; Park, D.-C.; Jung, G.-W.; Cho, H.-R.; Lee, S.-Y.; Shin, J.W.; Baek, K.M.; Choi, J.-S. Ingestion of Exopolymers from Aureobasidium pullulans Reduces the Duration of Cold and Flu Symptoms: A Randomized, Placebo-Controlled Intervention Study. Evid.-Based Complement. Altern. Med. 2018, 2018. [CrossRef] [PubMed]

69. Li, Y.; Chi, Z.; Wang, G.Y.; Wang, Z.P.; Liu, G.L.; Lee, C.F.; Ma, Z.C.; Chi, Z.M. Taxonomy of Aureobasidium Spp. and Biosynthesis and Regulation of Their Extracellular Polymers. Crit. Rev. Microbiol. 2015, 41, $228-237$. [CrossRef] [PubMed]

70. Arapoglou, D.; Israilides, C.J.; Bocari, M.; Scanlon, B.; Smith, A.; Thessaly, U.; Thessaloniki, A.U. A Novel Approach to Grape Waste Treatment. In Protection and Restoration of the Environment VI: Proceedings of the International Conference; Center for Environmental Systems at Stevens Institute of Technology: Skiathos, Greece, 2002; p. 469.

71. Arvanitoyannis, I.S.; Ladas, D.; Mavromatis, A. Potential Uses and Applications of Treated Wine Waste: A Review. Int. J. Food Sci. Technol. 2006, 41, 475-487. [CrossRef]

72. Israilides, C.; Scanlon, B.; Smith, A.; Harding, S.E.; Jumel, K. Characterization of Pullulans Produced from Agro-Industrial Wastes. Carbohydr. Polym. 1994, 25, 203-209. [CrossRef]

73. Feng, J.; Yang, J.; Li, X.; Guo, M.; Wang, B.; Yang, S.T.; Zou, X. Reconstruction of a Genome-Scale Metabolic Model and in Silico Analysis of the Polymalic Acid Producer Aureobasidium pullulans CCTCC M2012223. Gene 2017, 607, 1-8. [CrossRef] [PubMed]

74. Feng, J.; Yang, J.; Yang, W.; Chen, J.; Jiang, M.; Zou, X. Metabolome- and Genome-Scale Model Analyses for Engineering of Aureobasidium pullulans to Enhance Polymalic Acid and Malic Acid Production from Sugarcane Molasses. Biotechnol. Biofuels 2018, 11, 94. [CrossRef] [PubMed]

75. Leathers, T.D.; Manitchotpisit, P. Production of Poly(Beta-L-Malic Acid) (PMA) from Agricultural Biomass Substrates by Aureobasidium pullulans. Biotechnol. Lett. 2013, 35, 83-89. [CrossRef] [PubMed]

76. Manitchotpisit, P.; Skory, C.D.; Peterson, S.W.; Price, N.P.; Vermillion, K.E.; Leathers, T.D. Poly(Beta-L-Malic Acid) Production by Diverse Phylogenetic Clades of Aureobasidium pullulans. J. Ind. Microbiol. Biotechnol. 2012, 39, 125-132. [CrossRef] [PubMed]

77. Kurosawa, T.; Sakai, K.; Nakahara, T.; Oshima, Y.; Tabuch, T. Extracellular Accumulation of the Polyol Lipids, 3,5-Dihydroxydecanoyl and 5-Hydroxy-2-Decenoyl Esters of Arabitol and Mannitol, by Aureobasidium Sp. Biosci. Biotechnol. Biochem. 1994, 58, 2057-2060. [CrossRef]

78. Price, N.P.; Manitchotpisit, P.; Vermillion, K.E.; Bowman, M.J.; Leathers, T.D. Structural Characterization of Novel Extracellular Liamocins (Mannitol Oils) Produced by Aureobasidium pullulans Strain NRRL 50380. Carbohydr. Res. 2013, 370, 24-32. [CrossRef] [PubMed]

79. Bischoff, K.M.; Leathers, T.D.; Price, N.P.J.; Manitchotpisit, P. Liamocin Oil from Aureobasidium pullulans Has Antibacterial Activity with Specificity for Species of Streptococcus. J. Antibiot. 2015, 68, 642. [CrossRef] [PubMed]

80. Kim, J.S.; Lee, I.K.; Yun, B.S. A Novel Biosurfactant Produced by Aureobasidium pullulans L3-GPY from a Tiger Lily Wild Flower, Lilium Lancifolium Thunb. PLoS ONE 2015, 10, e0122917. [CrossRef] [PubMed]

81. Manitchotpisit, P.; Price, N.P.J.; Leathers, T.D.; Punnapayak, H. Heavy Oils Produced by Aureobasidium pullulans. Biotechnol. Lett. 2011, 33, 1151-1157. [CrossRef] [PubMed]

82. Manitchotpisit, P.; Watanapokasin, R.; Price, N.P.; Bischoff, K.M.; Tayeh, M.; Teeraworawit, S.; Kriwong, S.; Leathers, T.D. Aureobasidium pullulans as a Source of Liamocins (Heavy Oils) with Anticancer Activity. World J. Microbiol. Biotechnol. 2014, 30, 2199-2204. [CrossRef] [PubMed]

83. Chi, Z.; Wang, X.X.; Ma, Z.C.; Buzdar, M.A.; Chi, Z.M. The Unique Role of Siderophore in Marine-Derived Aureobasidium pullulans HN6.2. Biometals 2012, 25, 219-230. [CrossRef] [PubMed]

84. Murugappan, R.; Karthikeyan, M.; Aravinth, A.; Alamelu, M. Siderophore-Mediated Iron Uptake Promotes Yeast-Bacterial Symbiosis. Appl. Biochem. Biotechnol. 2012, 168, 2170-2183. [CrossRef] [PubMed] 
85. Wang, W.; Chi, Z.; Liu, G.; Buzdar, M.A.; Chi, Z.; Gu, Q. Chemical and Biological Characterization of Siderophore Produced by the Marine-Derived Aureobasidium pullulans HN6.2 and Its Antibacterial Activity. Biometals 2009, 22, 965-972. [CrossRef] [PubMed]

86. Wang, W.L.; Chi, Z.M.; Chi, Z.; Li, J.; Wang, X.H. Siderophore Production by the Marine-Derived Aureobasidium pullulans and Its Antimicrobial Activity. Bioresour. Technol. 2009, 100, 2639-2641. [CrossRef] [PubMed]

87. Tjamos, E.C.; Tjamos, S.E.; Antoniou, P.P. Biological Management of Plant Diseases: Highlights on Research and Application. J. Plant Pathol. 2010, S17-S21.

88. Blakeman, J.P.; Fokkema, N.J. Potential for Biological Control of Plant Diseases on the Phylloplane. Annu. Rev. Phytopathol. 1982, 20,167-190. [CrossRef]

89. Money, N.P. Fungi and Biotechnology. In The Fungi, 3rd ed.; Elsevier: Amsterdam, The Netherlands, 2015; pp. 401-424.

90. Chi, Z.; Yan, K.; Gao, L.; Li, J.; Wang, X.; Wang, L. Diversity of Marine Yeasts with High Protein Content and Evaluation of Their Nutritive Compositions. J. Mar. Biol. Assoc. UK 2008, 88, 1347-1352. [CrossRef]

91. Mina, M.; Tsaltas, D. Contribution of Yeast in Wine Aroma and Flavour. In Yeast-Industrial Applications; InTech: Rijeka, Croatia, 2017.

92. Fugelsang, K.C.; Edwards, C.G. Wine Microbiology: Practical Applications and Procedures; Springer Science \& Business Media: Berlin, Germany, 2007.

93. Liu, J.; Sui, Y.; Wisniewski, M.; Droby, S.; Liu, Y. Utilization of Antagonistic Yeasts to Manage Postharvest Fungal Diseases of Fruit. Int. J. Food Microbiol. 2013, 167, 153-160. [CrossRef] [PubMed]

94. Bencheqroun, S.K.; Bajji, M.; Massart, S.; Bentata, F.; Labhilili, M.; Achbani, H.; El Jaafari, S.; Jijakli, M.H. Biocontrol of Blue Mold on Apple Fruits by Aureobasidium pullulans (Strain Ach 1-1): In Vitro and in Situ Evidence for the Possible Involvement of Competition for Nutrients. Commun. Agric. Appl. Biol. Sci. 2006, 71 Pt 3B, 1151-1157.

95. Bencheqroun, S.K.; Bajji, M.; Massart, S.; Labhilili, M.; El Jaafari, S.; Jijakli, M.H. In Vitro and in Situ Study of Postharvest Apple Blue Mold Biocontrol by Aureobasidium pullulans: Evidence for the Involvement of Competition for Nutrients. Postharvest Biol. Technol. 2007, 46, 128-135. [CrossRef]

96. Schena, L.; Nigro, F.; Pentimone, I.; Ligorio, A.; Ippolito, A. Control of Postharvest Rots of Sweet Cherries and Table Grapes with Endophytic Isolates of Aureobasidium pullulans. Postharvest Biol. Technol. 2003, 30, $209-220$. [CrossRef]

97. Mari, M.; Martini, C.; Spadoni, A.; Rouissi, W.; Bertolini, P. Biocontrol of Apple Postharvest Decay by Aureobasidium pullulans. Postharvest Biol. Technol. 2012, 73, 56-62. [CrossRef]

98. Di Francesco, A.; Ugolini, L.; Lazzeri, L.; Mari, M. Production of Volatile Organic Compounds by Aureobasidium pullulans as a Potential Mechanism of Action against Postharvest Fruit Pathogens. Biol. Control 2015, 81, 8-14. [CrossRef]

99. Farbo, M.G.; Urgeghe, P.P.; Fiori, S.; Marcello, A.; Oggiano, S.; Balmas, V.; Hassan, Z.U.; Jaoua, S.; Migheli, Q. Effect of Yeast Volatile Organic Compounds on Ochratoxin A-Producing Aspergillus Carbonarius and A. Ochraceus. Int. J. Food Microbiol. 2018, 284, 1-10. [CrossRef] [PubMed]

100. Di Francesco, A.; Roberti, R.; Martini, C.; Baraldi, E.; Mari, M. Activities of Aureobasidium pullulans Cell Filtrates against Monilinia Laxa of Peaches. Microbiol. Res. 2015, 181, 61-67. [CrossRef] [PubMed]

101. Ferraz, L.P.; Cunha, T.D.; da Silva, A.C.; Kupper, K.C. Biocontrol Ability and Putative Mode of Action of Yeasts against Geotrichum Citri-Aurantii in Citrus Fruit. Microbiol. Res. 2016, 188-189, 72-79. [CrossRef] [PubMed]

102. Pfliegler, W.P.; Pusztahelyi, T.; Pócsi, I. Mycotoxins-prevention and Decontamination by Yeasts. J. Basic Microbiol. 2015, 55, 805-818. [CrossRef] [PubMed]

103. Vanhoutte, I.; Audenaert, K.; De Gelder, L. Biodegradation of Mycotoxins: Tales from Known and Unexplored Worlds. Front. Microbiol. 2016, 7, 561. [CrossRef] [PubMed]

104. De Felice, D.V.; Solfrizzo, M.; De Curtis, F.; Lima, G.; Visconti, A.; Castoria, R. Strains of Aureobasidium pullulans Can Lower Ochratoxin A Contamination in Wine Grapes. Phytopathology 2008, 98, 1261-1270. [CrossRef] [PubMed]

105. Zhang, X.; Yang, H.; Apaliya, M.T.; Zhao, L.; Gu, X.; Zheng, X.; Hu, W.; Zhang, H. The Mechanisms Involved in Ochratoxin A Elimination by Yarrowia Lipolytica Y-2. Ann. Appl. Biol. 2018, 163, 164-174. [CrossRef] 
106. Amézqueta, S.; González-Peñas, E.; Murillo-Arbizu, M.; de Cerain, A.L. Ochratoxin A Decontamination: A Review. Food Control 2009, 20, 326-333. [CrossRef]

107. Zhang, H.; Apaliya, M.T.; Mahunu, G.K.; Chen, L.; Li, W. Control of Ochratoxin A-Producing Fungi in Grape Berry by Microbial Antagonists: A Review. Trends Food Sci. Technol. 2016, 51, 88-97. [CrossRef]

108. Verginer, M.; Leitner, E.; Berg, G. Production of Volatile Metabolites by Grape-Associated Microorganisms. J. Agric. Food Chem. 2010, 58, 8344-8350. [CrossRef] [PubMed]

109. Campisano, A.; Pancher, M.; Puopolo, G.; Puddu, A.; Lòpez-Fernàndez, S.; Biagini, B.; Yousaf, S.; Pertot, I. Diversity in Endophytic Populations Reveals Functional and Taxonomic Diversity between Wild and Domesticated Grapevines. Am. J. Enol. Vitic. 2014, 66, 12-21. [CrossRef]

110. Campisano, A.; Antonielli, L.; Pancher, M.; Yousaf, S.; Pindo, M.; Pertot, I. Bacterial Endophytic Communities in the Grapevine Depend on Pest Management. PLoS ONE 2014, 9, e112763. [CrossRef] [PubMed]

111. Merin, M.G.; Martin, M.C.; Rantsiou, K.; Cocolin, L.; de Ambrosini, V.I. Characterization of Pectinase Activity for Enology from Yeasts Occurring in Argentine Bonarda Grape. Braz. J. Microbiol. 2015, 46, 815-823. [CrossRef] [PubMed]

112. Merin, M.G.; Mendoza, L.M.; Morata de Ambrosini, V.I. Pectinolytic Yeasts from Viticultural and Enological Environments: Novel Finding of Filobasidium Capsuligenum Producing Pectinases. J. Basic Microbiol. 2014, 54, 835-842. [CrossRef] [PubMed]

113. Mulay, Y.R.; Deopurkar, R.L. Purification, Characterization of Amylase from Indigenously Isolated Aureobasidium pullulans Cau 19 and Its Bioconjugates with Gold Nanoparticles. Appl. Biochem. Biotechnol. 2018, 184, 644-658. [CrossRef] [PubMed]

114. Kudanga, T.; Mwenje, E. Extracellular Cellulase Production by Tropical Isolates of Aureobasidium pullulans. Can. J. Microbiol. 2005, 51, 773-776. [CrossRef] [PubMed]

115. Kudanga, T.; Mwenje, E.; Mandivenga, F.; Read, J.S. Esterases and Putative Lipases from Tropical Isolates of Aureobasidium pullulans. J. Basic Microbiol. 2007, 47, 138-147. [CrossRef] [PubMed]

116. Martins, M.A.; Lima, N.; Silvestre, A.J.; Queiroz, M.J. Comparative Studies of Fungal Degradation of Single or Mixed Bioaccessible Reactive Azo Dyes. Chemosphere 2003, 52, 967-973. [CrossRef]

117. Kremnicky, L.; Slavikova, E.; Mislovicova, D.; Biely, P. Production of Extracellular Beta-Mannanases by Yeasts and Yeast-like Microorganisms. Folia Microbiol. 1996, 41, 43-47. [CrossRef]

118. Augustin, J. Polysaccharide Hydrolases of Aureobasidium pullulans. Folia Microbiol. 2000, 45, $143-146$. [CrossRef]

119. Sheng, L.; Tang, G.; Su, P.; Zhang, J.; Xiao, Q.; Tong, Q.; Ma, M. Understanding the Influence of Tween 80 on Pullulan Fermentation by Aureobasidium pullulans CGMCC1234. Carbohydr. Polym. 2016, 136, 1332-1337. [CrossRef] [PubMed]

120. Roukas, T.; Serris, G. Effect of the Shear Rate on Pullulan Production from Beet Molasses by Aureobasidium pullulans in an Airlift Reactor. Appl. Biochem. Biotechnol. 1999, 80, 77-89. [CrossRef]

121. Lazaridou, A.; Biliaderis, C.G.; Roukas, T.; Izydorczyk, M. Production and Characterization of Pullulan from Beet Molasses Using a Nonpigmented Strain of Aureobasidium pullulans in Batch Culture. Appl. Biochem. Biotechnol. 2002, 97, 1-22. [CrossRef]

122. Roukas, T. Pullulan Production from Deproteinized Whey by Aureobasidium pullulans. J. Ind. Microbiol. Biotechnol. 1999, 22, 617-621. [CrossRef] [PubMed]

123. Muramatsu, D.; Okabe, M.; Takaoka, A.; Kida, H.; Iwai, A. Aureobasidium pullulans Produced Beta-Glucan Is Effective to Enhance Kurosengoku Soybean Extract Induced Thrombospondin-1 Expression. Sci. Rep. 2017, 7, 2831. [CrossRef] [PubMed]

124. Aoki, S.; Iwai, A.; Kawata, K.; Muramatsu, D.; Uchiyama, H.; Okabe, M.; Ikesue, M.; Maeda, N.; Uede, T. Oral Administration of the $\beta$-Glucan Produced by Aureobasidium pullulans Ameliorates Development of Atherosclerosis in Apolipoprotein E Deficient Mice. J. Funct. Foods 2015, 18, 22-27. [CrossRef]

125. Muramatsu, D.; Kawata, K.; Aoki, S.; Uchiyama, H.; Okabe, M.; Miyazaki, T.; Kida, H.; Iwai, A. Stimulation with the Aureobasidium pullulans-Produced Beta-Glucan Effectively Induces Interferon Stimulated Genes in Macrophage-like Cell Lines. Sci. Rep. 2014, 4, 4777. [CrossRef] [PubMed]

126. Leathers, T.D.; Price, N.P.; Bischoff, K.M.; Manitchotpisit, P.; Skory, C.D. Production of Novel Types of Antibacterial Liamocins by Diverse Strains of Aureobasidium pullulans Grown on Different Culture Media. Biotechnol. Lett. 2015, 37, 2075-2081. [CrossRef] [PubMed] 
127. Di Francesco, A.; Ugolini, L.; D’Aquino, S.; Pagnotta, E.; Mari, M. Biocontrol of Monilinia Laxa by Aureobasidium pullulans Strains: Insights on Competition for Nutrients and Space. Int. J. Food Microbiol. 2017, 248, 32-38. [CrossRef] [PubMed]

128. Di Francesco, A.; Mari, M.; Ugolini, L.; Baraldi, E. Effect of Aureobasidium pullulans Strains against Botrytis Cinerea on Kiwifruit during Storage and on Fruit Nutritional Composition. Food Microbiol. 2018, 72, 67-72. [CrossRef] [PubMed]

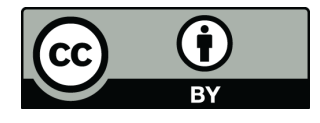

(C) 2018 by the authors. Licensee MDPI, Basel, Switzerland. This article is an open access article distributed under the terms and conditions of the Creative Commons Attribution (CC BY) license (http:/ / creativecommons.org/licenses/by/4.0/). 